\title{
THE
}

UNIVERSITY

University of Rhode Island

OF RHODE ISLAND

DigitalCommons@URI

\section{Information Provision and the Carceral State: Race and Reference beyond the Idea of the "Underserved"}

Jeanie Austin

Melissa Villa-Nicholas

University of Rhode Island, mvnicholas@uri.edu

Follow this and additional works at: https://digitalcommons.uri.edu/lsc_facpubs

The University of Rhode Island Faculty have made this article openly available.

Please let us know how Open Access to this research benefits you.

This is a pre-publication author manuscript of the final, published article.

Terms of Use

This article is made available under the terms and conditions applicable towards Open Access Policy Articles, as set forth in our Terms of Use.

\section{Citation/Publisher Attribution}

Austin, Jeanie, \& Villa-Nicholas, Melissa. (2019). Information Provision and the Carceral State: Race and Reference beyond the Idea of the "Underserved". The Reference Librarian, 60(4), 233-261.

Available at: https://doi.org/10.1080/02763877.2019.1645077

This Article is brought to you for free and open access by the Graduate School of Library and Information Studies at DigitalCommons@URI. It has been accepted for inclusion in Graduate School of Library and Information Studies Faculty Publications by an authorized administrator of DigitalCommons@URI. For more information, please contact digitalcommons-group@uri.edu. 
Information Provision and the Carceral State: Race and Reference Beyond the Idea of the "Underserved"

\begin{abstract}
:
This article addresses an approach to library services for people who are incarcerated that meets the situated information needs and desires of people within jails and prisons. By creating a flow of information between LIS students and individuals who are incarcerated through a Reference by Mail program, resources available to incarcerated people are increased while students engage in a humanizing and self-reflexive project, with the understanding that the regulation of information within jails and prisons has lasting effects for the life chances of incarcerated people.
\end{abstract}

Keywords: Incarceration, Information Access, LIS education, Racial Capitalism, Reference by Mail 


\section{Introduction}

As a profession structured in whiteness, library and information science (LIS) must reckon with the long histories of white supremacy and Othering that have shaped it, and vice versa. This article explores one possible mediation of the whiteness of LIS, specifically LIS education by describing a project- Reference by Mail, a mail in reference service from incarcerated patrons- that incorporates struggles that Black, Indigenous, and other activists and researchers of color have deemed critical to the life chances of people who experience racialized oppression. This article draws from research on the criminalization and incarceration of people of color (including Black and brown women and LGBTQ people of color) alongside an evaluation of the role of LIS in upholding the structures that reinforce individual and systemic forms of criminalization and racialized State violence (Alexander, 2010; Bernstein, 2014; Davis, 2003; Fine \& Ruglis, 2009; Gilmore, 2007; Spade, 2011; Stanley \& Smith, 2011). By utilizing an LIS classroom project that positions future LIS professionals as responsible for information provision to people who are incarcerated, this work presents an intervention into the whiteness of the profession and reveals the professions' role in replicating and furthering processes of criminalization.

LIS literature on library services to people who are incarcerated in the United States reflects the overall view of librarians toward people who are criminalized and experience racialized State violence through incarceration. This article's literature review is focused on LIS professionals' writings about services to people who are incarcerated. The Reference by Mail project described in this article disturbs the racial capitalist and dehumanizing conceptions that LIS professionals utilize when conceiving of their patron base by broadening the defining scope of "patrons" to include people who are incarcerated. Reference by Mail does this by acting as a 
point of contact for LIS students, who are, for the most part, white (DataUSA, n.d.), and people who are incarcerated, who, due to racism in policing and criminalization, are often likely to be people of color (NAACP, 2019; Nellis, 2016).

A review of literature on library services to people who are incarcerated reveals that exposure is not a guarantee of humanization or responsible information provision. Critical theoretical understandings of how library service is an act of anti-racist librarianship are a necessary element of beginning to work against the pervasive histories of whiteness within LIS. By focusing on race and power within LIS literature on services to incarcerated people, this research forefronts the creation of a Reference by Mail project that encourages LIS students to critically grapple with how whiteness and white supremacy inform the discipline in ways that echo the systemic, structuring forces of policing and incarceration. The Reference by Mail service described here incorporates descriptions of the prison-industrial complex with Melamed's (2015) definition of racial capitalism in order to interrogate previous research on library services to people who are incarcerated and to critically position Reference by Mail services as a needed aspect of public library services and LIS education. Theorists of racial capitalism focus on processes of dehumanization as a central aspect of maintaining social and economic hierarchies. Dehumanization is central to the continuing functioning of the prisonindustrial complex. Humanization, then, is an essential component of undoing some of the harms of policing and incarceration. Humanization is key to the administration of Reference by Mail as a central aspect of LIS coursework.

The State maintains power and works to dehumanize people inside of jails and prisons by regulated access to information, or denial of that access. Providing information that is in response to the inquiries, needs, and desires expressed by people who are incarcerated is an 
obvious counter to ongoing systems of State control. An examination of previous LIS literature on services to incarcerated people reveals there is little precedent within librarianship for providing critically-situated information to people who are subjected to intense State scrutiny and limited information access. This article outlines one possible approach to creating a model for information provision to people inside of U.S. jails and prisons that recognizes the humanity of people who are incarcerated. It details a project that pushes against State forces that limit the information access of people detained inside of jails and prisons by providing a Reference by Mail service that accepts and responds to the information requests of people who are incarcerated. Simultaneously, it offers a mode of addressing the ongoing ideological approaches to people in jails and prisons that continue to define librarianship as a profession by involving LIS students in the process of responding to letters from patrons who are inside, encouraging students to recognize the varied humanity of people in jails and prisons as illustrated through the breadth and variety of their information requests.

Patrons of Reference by Mail send their reference requests from inside of jails and prisons all over the country. Patron requests are received at a central public library address. Librarians who oversee the Reference by Mail service open, anonymize, number letters for the purposes of tracking responses, and scan the letters from people in jails and prisons. Scans of the processed letters are electronically sent to LIS student respondents, who are both online and on campus, as PDFs. The model provided in this article was based in lessons learned by implementing a Reference by Mail poject in an LIS class at the the university. The description of the university's LIS program illustrates that it is demographically and functionally similar to LIS schools across the country. Drawing from implementation of a Reference by Mail project in an on-line learning environent, the article provides a framework for the implementation of 
Reference by Mail in core coursework in LIS class design and provides philosophical, ethical, and theoretical concepts to encourage students to engage in anti-racist librarianship and to recognize and begin to dismantle the whiteness of the profession. It positions LIS, a profession defined by whiteness, as complicit in the ongoing normalization of the prison-industrial complex.

\section{The Graduate School of Library and Information Studies at the the university}

Graduate students training to become librarians from the the university's Graduate School of Library and Information Studies (GSLIS) are working as interns through the course LSC 504: Searching for Answers: Meeting Users' Information Needs, a core required course where students learn information seeking practices for different populations in the library setting.

GSLIS is an ALA accredited small regional library program. Like most of LIS, students are mostly white women with an increasing population of white men. Students are geographically from the area, and go on to be employed at local public, academic, and School Media libraries in New England (College Self-Study, 2017). At the time this article was written, LIS students attend courses in person, online, and in hybrid format. GSLIS' student body thrives in age diversity, with students ranging from their early 20 s into their 60 s, and some students have come directly from their undergrad degree while others have established families, are moving into second careers, and obtaining their MLS while working, often, in a library or in multiple jobs. Age distribution of GSLIS students has remained stable during the review period, with the same median age of 32 in 2010 and 2016, with the median fluctuating only slightly from 31-37 during the period (College Self-Study, 2017). In many ways the LIS program at the college reflects the general populations of students in library schools across the country overwhelmingly white women, moving into their second careers, and working multiple jobs while attending graduate school. Students are also increasingly experiencing and prefer online 
Information Provision and the Carceral State 6

learning to juggle their work, families, and school. The GSLIS program itself is a small regional library program that is over fifty years old. Its subject specialties include training School Library Media students (who are mostly already established in School Media Libraries and are emergency certified while obtaining their degrees), Library Leadership, and general library education. Almost all students find full time work in libraries before or quickly after graduation (College Self-Study, 2017).

It is in this context that we study the implementation of Reference by Mail in partnership with LIS. However, we first want to give the broader context of the prison-industrial complex as a racial project, and how that is situated within racial capitalism.

\section{Background: Racial Capitalism and the Prison-Industrial Complex}

Melamed states that racism and capitalism have always been conjoined to further the interests of the elite and to justify State violence (2015). In creating an outline for activist actions against racial capitalism, Melamed utilizes Harvey's conceptualization of the current form of neoliberalism to outline the "state-finance-racial violence nexus" that justifies racialized violence through "the inseparable confluence of political/economic governance with racial violence which allows ongoing accumulation through dispossession by calling forth the spectre of race (as threat) to legitimate State counterviolence in the interest of financial asset owning classes..." (2015, p. 78). The ability to name, separate, and include are seen as powers of the State and the elite. Under neoliberal logics, exclusion and inclusion each work to minimize people to racial or identity groupings that subsume the fullness of humanity and relationships. Melamed points to the activist potential of addressing this separation in Indigenous movements such as Idle No More, which "work for the well-being of the widest conceivable collective... interconnected through nonlinear time and space" (2015, p. 84). 
The concept of nonlinear time and space applies directly to the prison-industrial complex, which is born from and based in long histories of American chattel slavery and integrates logics of inherent criminality, rightlessness, and recapitulation theory and is an institution founded in racial capitalist violence (Bauer, 2018; Cacho, 2012; Calathes, 2017; Lesko 1996). In its current instantiation, the prison-industrial complex can be defined as "the overlapping interests of government and industry that use surveillance, policing, and imprisonment as solutions to economic, social and political problems" (Critical Resistance, 2018). Numerous scholars, people who are incarcerated, and activists on the outside have worked to elucidate the operations of the prison-industrial complex, linking racism and capitalism as its structuring tenets. Notable research that addresses this topic includes Michelle Alexander's The New Jim Crow (2010), Angela Davis' Are Prisons Obsolete (2003), Ruth Wilson Gilmore's Golden Gulag: Prisons, Surplus, Crisis, and Opposition in Globalizing California (2007), and Dean Spade's Normal Life: Administrative Violence, Critical Trans Politics, and the Limits of Law (2011). Scholars and activists have established that the structuring power of white supremacy shapes the landscape of the prison and perceptions of who constitutes the public (especially as people in jail and prison are removed from association with publics and public spaces).

The racialized aspects of policing and incarceration (and the institutional ties of these practices to other forms of discipline, such as the school-to-prison pipeline) are welldocumented. In brief, nearly 2.3 million people are currently incarcerated in the United States. ${ }^{1}$ Of that 2.3 million, nearly $40 \%$ of people who are incarcerated in the United States are Black (this varies by state and compounds with poverty levels and local level policing practices) (Brett, 2016; Sakala, 2014). Prison labor generates billions of dollars in profits and profits are shared between governments and private corporations. The prison strikes of 2016 and 2018 attest to the 
low wage, exploitative labor practices utilized in prisons while also illustrating the humanity and power of people held inside of U.S. jails and prisons. Carceral terrains overlay many areas of Americans' day-to-day lives and frame American society - from community level policing and public funding for increasing militarization of police forces, to the prison labor exploited to produce name-brand merchandise, to the implementation of for-profit prisons, to the vast number of people who are on probation, parole, electronic monitoring, or other types of continued State surveillance (Ritchie \& Richie, 2017).

People who are surveilled, policed, and incarcerated describe processes of racialized capitalism implemented through ongoing individual and collective dehumanization (Bustamante, Joshani, \& Stoudt, 2018). Drawing from an analysis of interviews with people who had experienced discretionary arrest in New York, Bustamante et al. theorize a psychological process of "cumulative dehumanization" instigated and maintained by State actors $(2018, \mathrm{p}$. 2). The researchers acknowledge the role of racial capitalism as a lived and sustained force in the lives of people targeted by the State. They describe cumulative dehumanization as

(i) an active condition of becoming, experienced as a temporal and spatial accumulation of dehumanizing moments, structurally imposed on racialized communities under siege; (ii) a wearing down of the racialized and affective body, creating circuits of dispossession for entire communities through time and across space; (iii) a product and (re)producer of the material and ideological modes undergirding racial capitalism; and (iv) a force met with individual and collective resistance. (p. 1)

In order to think through LIS' historical culpability in limiting (or failing to facilitate) information access to people who are incarcerated, this research utilizes the lens of racial capitalism to disentangle processes of State control and white supremacy (Melamed, 2015). The 
concept of racial capitalism provides a lens for linking histories of State control through labor, slavery, and the present day prison-industrial complex. Racial capitalism involves not only the objectifying and Othering of people of color [and other people who are slated for social death by State practice (Cacho, 2012; Patterson, 1982)], it also functions through an ongoing process of separation and dehumanization (Bustamante, Joshani, \& Stoudt, 2018; Melamed, 2015).

Research and literature on library services to people in jails and prisons often reiterate and further this dehumanization - positioning people who are incarcerated as Other, less than human, inferior, or in need of (white) salvation. While some literature in the field pushes against these types of portrayals, the dominant narrative within LIS serves to normalize and support the ongoing racial capitalist functions of the prison-industrial complex.

\section{Identifying Racial Capitalism in Library Literature on Services to People Who Are Incarcerated}

Traditionally, library services have reinforced the larger project of the State, especially on matters around race, gender, sexuality and class. Historically the U.S. public library has normalized and made invisible the whiteness of the profession, by, for instance, prioritizing the assimilation and English-only model of immigration through programming and collections (Honma, 2005). Librarianship reinforces the State through its historical enactment and through current practices. Compared to the deep impact that critical theory has had on fields in the social sciences and humanities, such as ethnic studies, gender studies, and education, LIS has often resisted or been slow to adapt to critical praxis (Wiegand, 2000). Over decades, scholars within LIS have called for an implementation of critical theory, with limited results (Elmborg, 2016; Pawley, 2006, Wiegand, 2000). 
There has been a gap within the literature in LIS in reflecting on race and especially the link between racism and criminalization. Librarianship and libraries in the United States have followed suit in the larger U.S. structures of race and racism, through library segregation and the protecting of white fragility, and have especially cloaked the whiteness of LIS under the softer terms of diversity and multiculturalism. In light of this, library services to people in jails and prisons must be examined within frames of power. Carceral institutions are sites where the States' aegis of racialized capitalist accumulation occurs through processes of psychic and physical separation and the cumulative dehumanization of people who daily come into contact with the extensive prison-industrial complex. ${ }^{2}$ The power of the prison-industrial complex exists in its quotidian functions and in its normalization as a necessary aspect of society.

Denormalizing the prison-industrial complex includes enacting a critique of racial capitalist processes of criminalization, dehumanization, and policing. Librarians must reckon with how descriptions of practical and theatrical aspects of library services within jails and prisons within LIS research further normalize systems of incarceration that dehumanize library patrons.

Library literature on services to people in jails and prisons repeatedly normalizes the role of incarceration - librarians writing on this subject rarely go so far as to critique the racial capitalist logics that support incarceration as a State practice. For example, The ALA statement on Prisoners' Right to Read positions carceral systems as necessary when "free people, through judicial procedure, segregate some of their own" (ALA, 2019a). The humanity of people detained in carceral institutions rose to the forefront of policies related to the rights of people in prisons at the ALA Midwinter 2019 session, where, after internal debate, the people-first language of "people who are incarcerated" and "incarcerated people" was adopted to replace the state-justifying language of "prisoners" (ALA, 2019b). Looking to library history, it becomes 
obvious that the normalization of the prison-industrial complex within librarianship ignores the ongoing rhetoric of punishment that has resulted in a decline of information access that was previously gained through the efforts of people who were incarcerated in the 1960s and 1970s (Sweeney, 2008). A punitive carceral system has been establishing in the United States since the 1980s (now nearly 40 years) and Supreme Court cases from the 1970s forward have limited the possibility for recourse against the State for people who are incarcerated (Sullivan, 2008). Despite research that illustrates that the U.S. prison-industrial complex has embraced punitive approaches and enacts forms of violence against people who have diminishing legal recourse, including in the area of information access, some librarians writing on the need for library services in carceral institutions still proclaim the possibility for the carceral institution to enforce rehabilitation. Few researchers in this area take as a central concern an interrogation of the supposed necessity of criminalization and incarceration or the ongoing role of racial capitalism. This occurs despite ALA's acknowledgement that dehumanization is a function of incarceration. Rarely does a publication deviate from some faith in the functioning purpose of incarceration. Some writers, like Coyle, whose 1987 Libraries in Prisons: A Blending of Institutions is still being utilized in LIS classrooms, advocate for the prison library to function as an extension of the prison itself, working within a framework of (sometimes) rehabilitation and (often) retribution. Writers in this tack emphasize the functioning of the prison, and the prison library, as forms of ongoing control. Bouchard and Winnicki provide a clear example of this approach in their discussion of contraband, arguing that a logic of internal safety in the prison is dependent on people inside of prisons having no power and that even possession of a book that has not been properly checked out should constitute possession of contraband - an argument that has real disciplinary consequences for people in prisons (2000). The ways in which racial 
capitalism is reproduced through separation, Othering, and cumulation dehumanizing is obvious in this approach. Also present is a fear that borders on the theatrical, wherein librarians view patrons as an undifferentiated mass, or as differentiated from one another almost exclusively in the type of crimes described in their convictions. Theatrical portrayals, which dehumanize and reduce library patrons to "thieves, rapists, and murderers" (Stearns 2004, 50), serve to perpetuate the ongoing role of carceral institutions as a "state-finance-racial violence nexus."

Normalization of carceral systems as part of the political and social landscape of the United States is evident in the co-creation of the 1992 Standards for Libraries in Correctional Institutions - a shared publication of the American Library Association and the American Correctional Association (,ad hoc subcommittee 1992). Lehmann, one of the contributors to the standards and the co-author of the International Federation of Library Associations Guidelines for Library Services to Prisoners, simultaneously argued that the "similarities between prison and public libraries are greater than the difference" and that librarians working with people in prison should "respect them as individual human beings" while emphasizing the assumed low literacy rates and emotional instability of people in prisons (Lehmann, 2000, p. 126, 127). Lehmann's statements reiterate a deficit approach that dehumanizes people who are incarcerated through racialized fears of criminality and need for intervention and resituates white, middle class forms of belonging (including emotional civility) as redemptive. It holds an echo of the White Lady Bountiful, a Progressive Era ideology that ignored racialized power differentials under the guise of (predominantly) white women as agents of civilization and enculturation (Meiners, 2017; Schlessleman-Tarango, 2016). The idea of the library as an agent of and responsible for individual "rehabilitation" into a presumptively functioning society carries 
Information Provision and the Carceral State 13

forward into the present, evident in the 2017 ASCGLA-sponsored workshop "The Prison Library as an Agent of Rehabilitative Change.”

The most recent turn in approaches to librarianship in jails and prisons draws from Vogel's 1995 Down for the Count, published the same year as Rubin and Suvak's Libraries Inside. Vogel takes a practical approach to libraries in prisons, arguing that they should function in a mode as similar to a public library as possible, and outlining how this might be possible. Clark and MacCraeigh's 2006 Library Services to the Incarcerated pursues this approach, which is restated in Vogel's 2009 The Prison Library Primer. Evident in the above texts is an attempt to disrupt librarians' conceptions of the public, but the claim of reentry as the only way back into the public at times falls short - it assumes that the isolating function of carceral institutions is complete, and does not transcend walls to affect families, friends, and communities in patterns of cumulative dehumanization.

Despite the large amount of research on and activism around the racialized nature of policing, library literature on services to people detained inside of jails and prisons rarely engages critically with processes of racialization and criminalization. Redemption, rehabilitation, and democratic belonging undergird the more humanizing approaches to librarianship for people inside of jails and prisons, ignoring that some people may be positioned by the State, and subject to State forces, in ways that functionally deny their humanity and access to citizenship through criminalization, stereotype, and systemic racism. Describing patrons as “menaces to society" (Stearns, 2004, p. 73) and noting librarians' belief that differences between their racialized experience (largely white) and that of their patrons (largely Black and brown) are unrelated to their assessment of their service (Shirley, 2003) denies the self-replicating power of 
white supremacy and serves the function of the prison as a tool of racialized capitalist accumulation and dehumanization.

A few researchers do address that carceral systems lead to cumulative dehumanization through racial capitalist violence. Higgins, writing for the Public Library Association, firmly positions library services to people in jails and prisons within a larger frame of how incarceration functions in the United States (2017), providing readers with practical information that is set within a recognition of racialized policing practices and mass incarceration. Arford (2016) discusses the role of librarians in prisons as always situated within power and resistance, noting the role of prisons as a project of dehumanization -

Given that the prison is arguably the most abhorred of all social institutions, containing the most dispossessed and excluded members of society, it is essential that we examine the ways in which individuals in this group affect and are affected by the decisions made by those in positions of authority and document the uses/abuses of power and the countless acts of resistance that occur not only as sensational events reported by the media, but perhaps more importantly, those that happen as part of mundane, everyday life. (p. 225)

The pressing issue of how the prison-industrial complex shapes everyday life, both inside and outside of the prison, is not lost on those who conduct research on the information and literacy practices of people who are most subject to State control. Chatman's "life in the round" (1999, p. 207) is founded in an examination of how women in prison created information worlds. Chatman also examined how those with privilege create forms of information poverty that negated the types of information and knowledge shared by people constructed as outsiders (1996). 
Sweeney's examination of power flows around reading and sharing information while incarcerated reveal some of the central questions that might shape an analysis of information provision to people in jails and prisons (2008). Sweeney (2008) offers a series of defining questions that outline the philosophical underpinnings of information access for people inside of jails and prisons:

Is reading in prison a right or a privilege? What are desirable outcomes of prisoners' engagements with books, and who should decide? And, finally, how do penal policies about reading reflect broader cultural and political uncertainties about prisoners' status as human beings capable of reflection and growth? (p. 667, emphasis ours)

It is a terrible fact that LIS students who have been steeped in the whiteness of the profession must often be taught to recognize the humanity of patrons in jails and prisons, but this is not specific only to services to people who are incarcerated. As Gohr articulates, the "unacknowledged whiteness and celebratory multiculturalism" (2017, p. 42) of librarianship continues to reverberate throughout the profession. Within the Reference by Mail project, students working with patrons who are incarcerated are encouraged to reflect on the intertwining systems of racial oppression and systems of incarceration. They are provided with background articles that describe processes of racial capitalism within systems of incarceration, including articles that discuss the information requests made by people in jails and prisons (Drabinski \& Rabina, 2015; Rabina \& Drabinski, 2015). Students are encouraged to utilize these resources as they think critically about why people inside of jails and prisons have not traditionally been considered a patron base deserving of library services, and to explore their own conceptions of how librarianship and systems of incarceration might operate through the same structures of white privilege and supremacy. These are tools students can utilize to critically evaluate library 
literatures that reflect the whiteness of the profession and to consider how whiteness within LIS adds to the accumulated dehumanization of people of color, both in and outside of jails and prisons. Part of this project is not to simply attempt to "solve" racism or implementations of whiteness in LIS services, but to encourage LIS students to sit with the tension and discomfort of the awareness of power.

\section{Reference by Mail}

\section{Critically Positioning Reference by Mail Services}

The Reference by Mail project situates practical aspects of library service within a frame of understanding the prison-industrial complex as a system of racial capitalist accumulation and exploitation. It is philosophically based in the recognition that the prison-industrial complex functions through the ongoing Othering and separation of people of color and other people most likely to be policed and incarcerated. This results in the cumulative dehumanization of people who are surveilled, policed, and incarcerated. Reference by Mail draws from existing public library programs that provide mail reference service to people inside of jails and prisons in the United States to provide tools for potentially disrupting or interceding in the present iteration of policing and incarceration of people in which a denial of information access is a form of State oppression. The State mandated and enforced limitation on information access is a tool of social and political control that has lasting effects on the life chances, well-being, and internal lives of people positioned within white supremacist systems as racialized Others in need of intervention, rehabilitation, or redemption (Chatman, 1996; Drabinski \& Rabina, 2015). Even when a wellstocked library exists within a carceral institution, it will be shaped by the ideological concerns of the institution and, due to censorship, spatial limitations, and other factors, there will be information that it lacks. Add to this the fact that prison (and at times, jail) populations are often 
quite large and access to library materials is limited by types of detainment within the institution (among many other factors), and it becomes obvious that even the most social justice oriented library within a prison cannot provide frequently accessible, comprehensive, and humanizing information access.

Outside of the information or materials available within the carceral institution, people who are incarcerated are often only able to access information by paying for phone calls, paying for access to email (when available), or through the United States Postal Service. Physical mail is at times the only available avenue for communication for indigent people who are incarcerated - under various State statutes for access to writing materials and stamped envelopes, people who are in State prisons should have a minimum level of access to this form of communication free of charge. All communications take place under surveillance of carceral institutions, and may be curtailed at any time if they are viewed as comprising the functioning of the institution.

Three existing projects and one defunct mail reference project were identified as providing examples of the applied aspects of a by-mail information service for people inside of jails and prisons. These are San Francisco Public Library's Reference by Mail service to people located in jails and prisons from the Midwest to the West coast, Harris County Public Library's by-mail service to people incarcerated in Texas, a former service orchestrated through the National Network of Libraries of Medicine (Couvillon \& Justice, 2016), and New York Public Library's foundational Reference by Mail service. New York Public Library's Reference by Mail service was the only identified Reference by Mail service available people in jails and prisons across the United States prior to the 2018 implementation of a by-mail service through San Francisco Public Library (Jacobson, 2018). 
New York Public Library's (NYPL) service stands as a model for creating and implementing a long-term Reference by Mail project. NYPL's by mail service began in the mid1980s, although documentation suggests that librarians providing services in New York jails were engaged in some form of reference service prior to this time (Jacobson, 2018; Prial, 1978). Through word of mouth promotion by patrons in jail and prison, the Library's service has expanded to respond to letters from people in jails and prisons across the United States (Kutner, 2015). NYPL's service is increasingly important for people who are incarcerated as shifts to dependence on digital information access curtail the information resources that are easily available to people in jails and prisons - with little or no access to the internet, people who are incarcerated must rely on their information networks and materials present in jails or prisons (which may or may not be up to date) to access information or to verify the accuracy of information. As early as the year 2000, librarians were attempting to address how the information age would restructure information access and how the lack of access to digital information and technology would further disadvantage people in jails and prisons (Sullivan, 2000). As there has been little or no increased internet access within jails and prisons in the two decades following Sullivan's prescient push for increased access, prisons and jails have maintained their function as sites of enacting State oppression by limiting access to information.

Drabinski and Rabina's discussion of integrating a Reference by Mail service into LIS coursework serves as inspiration for a Reference by Mail service that works around the State power to limit information while addressing how LIS is composed through and reproduces logics of whiteness as a form of belonging in the field (Drabinski \& Rabina, 2015; Rabina \& Drabinski, 2015). The project outlined below simultaneously meets the immediate information requests made by people in jails and prisons while also denaturalizing incarceration, disrupting narratives 
of the "Other" that are explicit or implicit in much LIS education, and providing a ground for students, who, in a discipline overrun by whiteness, often do not recognize the humanity of library patrons who experience state oppression and the complexities of patrons' resistance to these forces. If students do not learn to recognize and work against the ways that white supremacy shapes the LIS profession, they will continuously dehumanize people and communities that are exploited through processes of racial capitalism. Given the ongoing neoliberal turn in LIS education, which increasingly moves students into online classrooms and emphasizes practical skills and workforce development over theoretical or ideological positions that underlie librarianship, the Reference by Mail project outlined here incorporates the online classroom as a site to be restructured toward an analysis of racial capitalism and accumulated dehumanization.

\section{Pedagogical Precedents}

Pedagogy situated in Critical Race Theory forefronts the approach to resisting State modes of penalty, implementing anti-racism, and critical reference with students prior to their interaction with Reference by Mail. Resisting the format of LIS that prioritizes whiteness by avoiding discussion around race and racism, this approach acknowledges the racial capitalist carceral system in the United States and the racialized systems of whiteness within LIS. This challenge can be approached in two ways: by educating students about the carceral system throughout the Reference by Mail project, and by executing the project through constantly reinstating the humanity of people inside of jails and prisons.

The process of answering questions and interacting with the Reference by Mail letters acts as an avenue of recognizing the humanity of patrons in jails and prisons, giving LIS students the opportunity to become more critical of the carceral State and to overcome separations 
reinforced by racial capitalist logics. By becoming aware of the information needs and desires of incarcerated patrons, LIS students are situated to have a stake in services to people who are incarcerated, as well as an awareness of how patrons who have been removed from the public through incarceration make up a large population of the United States.

Critical theoretical positions form the pedagogical foundations for a project that surpasses the walls of the jail or prison and the distances perpetuated by neoliberal turns within online education in LIS. Alongside the claims to and for increased equity and diversity in library services, numerous scholars in the field have argued the necessity of addressing library histories of colonialism, nationalism, whiteness, and resource guarding (Honma, 2005; Peterson, 1996; Schlessleman-Tarango, 2016; Velez and Villa-Nicholas, 2017; Weigand, 2000). Despite a variety of diversity initiatives in LIS education that have been implemented, at times as a response to student's direct demands (Cooke, Noble, \& Sweeney, 2016), the profession remains largely culturally and physically composed through whiteness (American Library Association, 2018). Research on the field has noted that the whiteness of the profession has negative effects on the experiences of librarians of color (Alabi, 2015). The explicit or implicit biases of a largely white student body in LIS compound with narratives of racialized people accused or convicted of a crime as Othered from the general public served by the public library. By providing quality reference services to people in jails or prisons, students are encouraged to work through their own dehumanizing biases that support the racial capitalist logics of the prisonindustrial complex. The goal of this project is for students to undo the limiting perspective they may have of the public so that they come to understand the public as including the 2.3 million people who are, at a any moment in the United States, inside of jails and prisons as well as the extensive networks of people who experience the ongoing effects of State practices of policing 
and incarceration. This simultaneously involves a reflection of whiteness, privilege, and an undoing of the normalization of biases that support the ongoing function of the prison-industrial complex.

Pedagogical precedents for this project can be found in the literature on teaching reference and experiential learning. Reference services and experiential/service learning have been linked to a reduction of bias in library services and to an increased level of skill development for LIS students. Reference tasks can expose students to variance in information requests made by people in jails and prisons (Drabinski \& Rabina, 2015), can introduce students to the practice of equity and access [an area identified by students as lacking in their LIS education (Kumasi \& Franklin Hill, 2011)], and can establish innovation and continual learning as part of the reference process (Roy, 2014). Experiential and service learning projects involving collaboration with community members and groups improve distance LIS education by providing students with an opportunity to implement and grow their skills as they learn (Angel, 2016). Service learning opportunities have been shown to increase students' civic-mindedness and awareness around others' experiences (Barrey, Lowe, \& Twill, 2017). Service and experiential learning increase students' awareness and facility with issues related to racialization and inequity (Overall, 2010; Vargas \& Erba, 2017). This form of educational project has been proposed as a way to meet the "gap" that LIS students often express between their experiences in classes and the real-world contexts of libraries (Colón-Aguirre, 2017). Providing reference service to people in jails and prisons as a part of the real-world, critically situated pedagogical imperative of this project provides students with a context to individually and collectively build skills, reflect on their own knowledge or lack of knowledge on the information worlds of people in jails and prisons, learn from people in jails and prisons about their various information needs 
and desires, and develop stronger understandings of how state power sets the limit of the "public" in ways that further racial capitalist projects of policing and incarceration.

The Reference by Mail project proposed here centers the experiences of people detained inside of jails and prisons, and the communities affected by policing, with the goal of recognizing and responding to the humanity of the people who are inside. In LIS, a field still entangled with its history of whiteness, this is not a neutral act. It situates students to address their own ideas of knowledge construction, stereotype, and the aftereffects of being criminalized and to seek new knowledges that do not align with whiteness. Experiential learning and reflection on the act of answering letters from people in jails and prisons facilitates students' own recognition of the impossibility for libraries to exist as neutral institutions and to recognize that, "[b]y legitimizing knowledge produced under the context of a white worldview, libraries unwittingly frame themselves as an overtly political institution that supports oppressive ideologies via the stance of neutrality." (Gohr, 2017, p. 44). They may begin to recognize the racialized structuring of information access through the obscurity of specific forms of information, the limits placed on interaction, and how they must also perform a professionalized (and often culturally white) form of communication in order to not be viewed as a threat to the functioning of carceral institutions, which would compromise information access for people inside of jails and prisons.

\section{Establishing Student Objectives}

Establishing assignment objectives and expectations are critical when analyzing racism within LIS services. In prefacing an assignment like Reference by Mail, or teaching race and racism in LIS, instructors drawing from the project described here can begin with the foundational aspects of Critical Race Theory (CRT). Aligning pedagogical goals for a 
collaboration between public library systems and online LIS classrooms with CRT's observations (adapted to LIS)

1. Racism is endemic to US life;

2. CRT [and LIS] must challenge ahistoricism and purse a contextual/historical analysis of social issues;

3. CRT is an interdisciplinary set of research practices that are still evolving and developing, and [need to be applied to LIS in depth; and]

4. CRT should incorporate the common experiences and shared experiences as the "other" that oppressed people bring to the struggle to reshape knowledge (Barnes, 1990). Race is always central to the analysis of social issues [in librarianship] when using CRT as the framework (Parsons \&Plakhotnic, 2006, p. 164)

This approach to critical LIS pedagogy bypasses the incepted loop of colorblindness and postracial perspectives that largely serve to normalize the carceral system in existing LIS literature on service to people in jails and prisons. It involves a consideration of the demographics of LIS programs and their stark, if not polar, contrast to the populations detained through racial capitalist systems of policing and incarceration. ${ }^{3}$

Incorporating CRT into LIS projects serves to diminish all attempts at colorblindness and denial of racism in society and within LIS. LIS has been in a racial echo chamber that has not allowed the field to move into mature understandings around race and racism, staying frozen in debates around whether racism exists, what Roberts and Noble name post-racialism in LIS (2016). The Reference by Mail project outlined here pushes against this phenomenon by positioning the service within a critical understanding of racial capitalism and accumulated dehumanization, and can be framed along the following learning objectives: 
1. To resist normalizing the racist carceral State while providing information services to patrons who are incarcerated.

2. To promote Intellectual freedom and equitable access to information.

3. To locate, retrieve, evaluate, and synthesize information from diverse sources to meet users' information needs.

4. To explain and apply the concepts, principles, theories, philosophies, and techniques of reference and user services in providing diverse individuals and groups with access to relevant and accurate recorded knowledge and information.

5. To demonstrate critical thinking skills.

6. To analyze and apply legal and ethical principles within which libraries and information agencies operate.

7. To communicate effectively to a range of audiences using written, oral, and digital media.

While objectives 2-7 follow standard objectives for assessment in LIS, this article advocates that LIS education must prioritize anti-racism as a primary pedagogical goal. Leading with antiracism in all forms of LIS practice, instead of making it secondary or invisible, will lead to a shift within the larger field of LIS. In the case of Reference by Mail, this shift is dependent on an analysis of racial capitalism, recognition of the extensive structuring reach of the prisonindustrial complex, and efforts to work against the accumulated dehumanization experienced by people who encounter policing and incarceration as everyday occurrences. Future librarians are encouraged to recognize that people inside of jails and prisons exist as the part of the patron base for library services. As Melamed (2015) insists, resistance to the systems that undergird white supremacy is possible when people denormalize the function of carceral institutions and 
reocgnize that they are rooted in a lineage of dehumanization, slavery, and persecution. The Reference by Mail project described here encourages librarians to follow the direction of Indigenous and other groups that lay claim to shared humanity and responsibility to one another and their surroundings and begin to "work for the well-being of the widest conceivable collective ... interconnected through nonlinear time and space" (2015, p. 84).

In order to work against racial capitalism, students should be provided with an analysis of how dehumanization occurs through anti-relationality. Anti-relationality is the idea that capitalism disjoins and deactivates relations between human beings, "forms of humanity are separated (made 'distinct') so that they may be 'interconnected' in terms that feed capital" (Gilmore, qtd. in Melamed, 2015 p. 78). Capitalism divides groups while simultaneously acting as the agent that binds them. This is especially relevant when thinking of incarcerated people, who, through dual processes of racialization and criminalization, have become a type of commodity for generating revenue for the state and producing cheap labor for industry. Racial capitalist understandings must also be held with anti-Blackness and the creation of disposable populations (Wang, 2018). Anti-relationality takes place not only in the systemic oppression furthered by white supremacy, but also in the separation that communities of color experience when a dramatic part of their population is removed from their geographic location. The Reference by Mail project can begin to reconnect the incarcerated person to some of the avenues that they have been dramatically separated from through anti-relationality.

This project does not assume that it occurs at a remove from racial capitalism, but one method of resistance to racial capitalism is to recognize the humanity of people who are incarcerated as something twined with the humanity of people who are not incarcerated or who directly benefit from white supremacy. Reference by Mail can be one way that people who are 
incarcerated are brought back into social relations, what Melamed calls, "new relations for nurturing total social being (which is more than human) through the material activities of living" (2015, p. 84). ${ }^{4}$

\section{Recognizing Humanity through Reference by Mail}

Public libraries serve a pivotal role in providing information for people in jails and prisons. Vogel emphasizes that all public librarians need an awareness of how to provide services to people (and, it can be extended, communities) that have experienced incarceration and its aftereffects (2009). Public librarians have often envisioned the public and the incarcerated Other as inherently separate. The extensive reach of the prison-industrial complex, and its underlying logics, defies this separation. Libraries serve people who have been incarcerated, people whose loved ones and community members are currently incarcerated, and people who experience the ongoing forces of cumulative dehumanization that is a feature of racial capitalism. Providing a Reference by Mail service for people in jails and prisons not only begins to meet their information requests, it also provides students with a tool to begin to recognize and name the role of white supremacy in the policing and incarceration that library patrons who are people of color directly or indirectly encounter. Training LIS students through a Reference by Mail assignment encourages students to reimagine patron bases, to view people who are incarcerated as part of the public served by libraries, and to critically evaluate how white supremacy has shaped LIS and the prison-industrial complex through processes of racial capitalism and dehumanization.

The Reference by Mail process is pedagogically framed by an initial meeting with the public librarian who oversees the service and positioned in the coursework an a necessary aspect of public library service. Prior to beginning the project, the public librarian meets with LIS 
students for an initial training and to inform them of the patrons' rights, and reviews the rules and regulations for answering Reference by Mail questions. Question and answer processes can be streamlined through group work, so that students can work on the answers together and can collectively reflect on what they are learning and their perspectives on the service. The process for incorporating students into Reference by Mail while simultaneously implementing anti-racist tools that denaturalize the surveillance State must be flexible and based in student's own processes of working against white supremacist logics that dehumanize people in jails and prisons. This means that, part of the pedagogy requires the educator and public librarian to be in constant revision reflecting on how students respond, to observe which activities promotes critical growth in the student, and to reflect on failures and revisions for improvement.

In order to support students in their reflection and reference work, librarians who administer the service draw from their knowledge of resources relevant to the patron's question to provide each student with a short description of the information request and potential search strategies with each PDF of a letter that is sent. Students receive the Rules \& Regulations for the service with every letter, and are provided with guidelines relevant to formatting their response. Guidelines include writing a short, introductory paragraph that professionally explains to the patron the processes that went into choosing a specific resource, an explanation of findings, and instructions to date the letter (which allows patrons to estimate the amount of time between when a letter was sent and when they personally receive it) and to sign the introductory letter with the name of the library system. The guidelines that are provided to LIS students ensure that patrons of the Reference by Mail service view the library as an institution that will continuously provide them with professionally sound information, will potentially gain insight into the research 
process, and will be alerted to any of their information requests that were not able to be answered within the 20 page limit.

A public library and LIS educational partnership allows LIS students to gain professional experience while public librarians oversee their work, critically engage them in discussions of policing and incarceration, and provide future librarians with examples of how public libraries can push against racial carceral logics in ways that combine theoretical positions with practical actions. Public librarians can assess student responses to determine whether or not they maintain a level of professionalism that should be inherent (and equitable) in all reference interactions, provide information that complies with the institutional constraints set by jails and prisons so as to not compromise people's access to information (typically by not sending individuallyidentifying information, maps, information about weapons, and by adhering to limitations regarding the amount and format of physical materials that people who are incarcerated can receive), and to assure that patrons in jails and prisons are receiving, at minimum, the quality of information that they would receive were they able to visit the public library. Librarians' interactions with students can help to frame how carceral institutions limit specific types of information and assist students in differentiating between the role of librarians and carceral staff in engaging in censorship. Librarians can also legitimate the reference and information requests made by people inside of jails and prisons, helping to describe how librarians' racialized processes of information evaluation work again patrons detained within jails and prisons.

The students' interactions with the librarian and course instructor are critical to student engagement. In the midst of interaction, the librarian and instructor can guide the students to notice their own personal biases about patrons who are in jails and prisons, and reveal partiality towards State ideology on citizenship and the prison-industrial complex. Because citizenship and 
the racial capitalist normativity of incarceration are quotidian habits, the intervention here is to change the normalized ideology around incarceration with praxis. The librarian and instructor can redirect students whose responses to a reference answer normalizes incarceration. This is part of an anti-racist intervention that recognizes the shared humanity of the student and the person in jail or prison and provides the student with tools to outline how their relative privilege is shaped by the oppression of people who are incarcerated.

The realities of incarceration are present within many of the Reference by Mail letters written by people who are incarcerated. Patrons frame their reference requests within their lived realities as a way of communicating the specificity of their requests. They may note the dearth of information that is available within the carceral facility, request information related specifically to prison policies and procedures, note that they are asking a question related to health because they have no other way to receive a second opinion, describe their plans for reentry in requesting specific resources, or note the conditions of the jail or prison in ways similar to noting the weather or time of day in personal letter writing. Patrons may have to communicate the conditions of their incarceration as an explanation for the amount of or type of information they can receive. As carceral facilities have varying rules, patrons may only be able receive a limited number of pages or images. Patrons who are confined in solitary conditions often must communicate their location within the jail or prison because it is directly related to the amount of or type of information they can receive. Patrons might also communicate how they will use the information. Examples of this might include a patron explaining that they sing lyrics to emotionally regulate themselves when they are unable to leave the cell for 23 hours a day (in solitary confinement), that they share health information with other people who are incarcerated that have similar questions, or that they utilize information from the resource to engage in 
recreational activities with other people who are incarcerated. Learning of the realities of incarceration as they are reiterated throughout the multiple letters students encounter can provide students with the perspective needed to denaturalize criminalization and incarceration - to simultaneously receive and respond to the affirmation of the humanity of people who are incarcerated and to question the legitimacy of jails and prisons as places where people are confined.

Patrons writing from within jails and prisons challenge the whiteness of LIS and the function of the prison-industrial complex through their reference requests. The authors of this article have provided the following artifical example questions to illustrate some of the breadth and depth of the questions received by a Reference by Mail service.

- What are publishers that take free submissions of prisoners writings through the mail? Does Kludge take submissions by mail?

- May I please have images and information about the Korean drama Devilish Joy along with a one-page image of the promotional poster if it is available?

- I'm getting out in six months and looking for housing for people with a sex offender conviction in the areas surrounding Tucson, AZ.

○ Please send me SOB x RBE “Anti” lyrics.

- I would like more information on non-profit or community organizations, such as Black Lives Matter.

- I am starting a cruelty-free cosmetics wholesale company when I am released. Please send me any and all information on what is required to start this company. A librarian can assist students in seeing how the strictures that the State places on information access within carceral institutions and culturally relevant interests are present 
within requests from patrons. For example, the initial question in the above list signals to the patrons' lack of monetary resources ("free submissions"), their State-enforced inability to access the internet ("through the mail"), and their lack of access to updated information (Kludge ceased publication in 2006). The second, fourth, and fifth questions all related to racialized experiences and cultural belonging. In answering these questions, students come to recognize patrons' interests as valid forms of information, while potentially reflecting on their own daily, casual access to media and information. The third and sixth questions communicate the harsh realities of criminal convictions. While answering the third question, the student is likely to find few resources for people with sexual assault convictions and may begin to ponder the nature of justice in a system that simultaneously decrees that a formal punishment has been enacted and concluded while placing individuals in situations that are so resource-bare upon their release. In answering the final question, the student might reflect on how criminal convictions on a person's record will limit their opportunities to obtain employment after their release from the jail or prison, and to see that entrepreneurship may be one of the few financial options available to people after their release.

The racialized nature of policing, criminalization, and incarceration can be interpreted through direct requests for information and in more subtle forms. Direct requests might concern histories of racialized groups, requests for images that are specific to religious or cultural practices and belonging, direct statements of racial identification or experience, or other forms of coded or direct expression. Additionally, students are provided with the first names of patrons so that the patron can be addressed appropriately within the text of the introductory paragraph. As noted in the study of librarians' responses to information requests made by people with names that indicate their racial belonging as either white or 
Black, librarians (and, it can be assumed, LIS students) are so steeped in whiteness that they may consciously or subconsciously reinforce structural oppression through the provision of subpar or limited information access (Corrado, Tonin, \& Vlassopoulos, 2017). The public librarian and LIS instructor have a role in guaranteeing that patrons inside of jails and prisons receive high-quality, well researched, and legitimating information, and can push students who enact a deference toward whiteness in their responses to assess their own role in providing quality information to all patrons.

Online LIS students and people in jails and prisons each stand at a sort of remove - the person in jail or prison is physically removed from the public(s), and the student is most often "present" in virtual classrooms. A great deal of projects that recognize the humanity of prisoners occur at this remove, which works to foreclose possibilities of humanity by subsuming individuals under the language of criminality, conviction, and the homogenizing label of the prisoner. Encounters with handwritten letters serves an important role in working against the monolithic identity of the criminal. In the United States, handwriting has come to symbolize individuality and intention, even if this was not historically the case (Thornton, 1996). Receiving handwritten letters, even when these arrive as digital and anonymized scans, introduces a contrast to students' lives as they are lived in public, digitally saturated information worlds. This is the contrast between the technologically mediated and possibly "unrecognized, latent" author (Ferguson, 2014, p. 54) and the physicality of the written word, which carries its history of interpretation, individual intention, physicality, and human presence even at a remove (Jackson 2015 Thornton, 1996).

The contrasts between students' and letter writers' access to technologies (word processors and digital files) are pronounced and may lead students to consider their conceptions 
of information access or equitable information provision as a human right. The majority of students now in LIS have come of age in the digital era. The person who is incarcerated is removed from access to technological progression. In the technologically mediated conception of the shared present, the handwritten letter takes on significance beyond even the selfhood conveyed in the individual forms of handwriting - it speaks to an individuation/individuality largely removed from social worlds and access to technologies and the information that access entails. A handwritten letter emphasizes not just the digital divide as a gap - it may reveal the gulf between the social, political, and physical worlds where students and people in jail or prison maintain themselves through information practice. The difference in form suggests how constraints set by the institution are communicated in even the most basic act of writing a letter to ask for information. ${ }^{5}$

At the end of the Reference by Mail project, students should be given a final metacognitive reflection wherein they are encouraged to examine at their own existing assumptions around incarceration and reflecting on the following questions:

- What did they learn about patrons working reference questions?

- What did they learn about the carceral State and librarianship?

- How can they resist normalization of prison while they are working in libraries? The elements discussed in this section - about names and implied or explicit racial identification of patrons, the ways that features of carceral facilities are used to frame information requests, how information requests reflect state-enforced information deficits through patrons' difficulty in accessing certain types of information, and how even the mode of communication - handwritten letters - conveys information regarding the differences between students' and patrons' access to 
technology and information. These should be highlighted within instructions to students and used to guide their metacognitive reflections.

Schlesselman-Tarango (2016), in “The Legacy of Lady Bountiful: White Women in the Library" looks at the "ways in which both patriarchy and white supremacy have acted upon and worked through the white female body, and more specifically how such a subject has been made manifest and moved within LIS" (p. 668). Matching LIS students with incarcerated patrons requires administrators to be mindful of the historical context of white womanness, as the majority of LIS graduate students are white women, enacting and being enacted by these white patriarchal structures that have framed the field. The Reference by Mail project envisioned here attempts to disrupt the "phenomenology of whiteness" in LIS, where whiteness projects and accumulates in spaces to further Other non-white librarians and patrons (Ahmed, 2007). It asserts that metacognitive reflection on learning about and from incarcerated patrons cannot happen in a vacuum and must not position patrons who are incarcerated at learning aids or ways of knowing the Other. The Reference by Mail project outlined here intentionally includes students in a reflective self-awareness of whiteness and white women as those who have traditionally upheld cultural standards of moral superiority, the missionary spirit of LIS, and implementing racial whiteness within librarianship to provide them with the tools needed to recognize that their own humanity is bound to the humanity of people in jails and prisons. By providing an ideological foundation of shared humanity that recognizes and pushes against carceral structures of power, oppression, and privilege, the Reference by Mail project outlined here works against the accumulation of whiteness as an unstated, though inherent, project of LIS.

In many ways, the incorporation of a Reference by Mail service into LIS classwork must recenter whiteness, even as whiteness is revealed as a field for critical interrogation. The 
overwhelming whiteness of LIS may erase the realities of students who have more direct experiences with policing, criminalization, and incarceration in their own lives. Librarians and instructors administering a Reference by Mail project should hold an awareness that students may be directly impacted by systems of incarceration, and take caution in the ways that they describe the project. This might be partially addressed by explicitly stating that the Reference by Mail service is always a response to the State-enforced lack of information people inside of jails and prisons experience. Positioning the service as a human-centered response is a way of denormalizing the prison-industrial complex and recognizing the fullness of individual patrons' lives, even as they are lived within carceral institutions. It works against ongoing processes of criminalization that circumscribe the entirety of people's existence under the rubrics of crime and punishment, recognizing that people are more than the harm they may have done, and that white supremacy structures the legal system in a way that shapes social and political definitions of which harms deserve State-led retributive action and even the very definition of "crime." In this frame, centering the importance of answering reference requests from people in jails and prisons rescripts the "unacknowledged whiteness and celebratory multiculturalism" (Gohr, 2017) present within LIS and library services, positions equity of information access as the work of social justice, and tacitly communicates to people inside of jails and prisons that they are considered part of the patron base of libraries, and that the public library is one of the resources available to them when they are released.

\section{Conclusion}

A review of library literature on services to people who are incarcerated reveals that the majority of researchers do not critically position these services. In contrast to former published approaches, the Reference by Mail project detailed in this article seeks to denormalize American 
systems of policing, criminalization, and incarceration. Concepts from racial capitalism and research into accumulated dehumanization are essential to assessing and intervening in the racialized processes of policing and incarceration. Reference by Mail is designed to recognize the humanity of patrons inside of jails and prisons, many of whom are Black, Indigenous, or people of color, by positioning information access as a human right. Simultaneously, the project described in this article encourages students to see themselves as capable of recognizing and disrupting the whiteness that has historically composed librarianship and librarians' views of the public by encouraging students to reimagine a public that includes the 2.3 million people incarcerated in America.

Beyond an assignment that assists the next generation of librarians in denormalizing carceral systems, the institutional implementation of services to people who are incarcerated has ramifications for library services to the general public. Narratives of criminality and racist caricatures of people who have experiences the cumulative dehumanization of the prisonindustrial complex shape librarians' interactions with people of color. Patrons can and do recognize when librarians (or libraries as institutions) share white supremacist understandings of race and criminalization that are enacted through the prison-industrial complex. Patrons who are maintaining a sense of their own dignity and humanity in the face of racial capitalist violence will not utilize a library that denigrates that effort. In this way, librarianship that conceptualizes library patrons who are people of color through logics similar to those of the State actively Others and dehumanizes patrons, potentially positioning people who have made informed decision to avoid the library due to its institutional whiteness as "underserved" and in need of (white) intervention. 
The aim of this paper is to support librarians and other LIS professionals to engage in a critical scrutiny of carceral institutions while also holding that there are millions of people whose lives are in some way constrained by these institutions. It offers an established means of addressing the lack of access to specific forms of information inside of jails and prisons through the provision of a direct library service as an educational opportunity for LIS students. The authors encourage projects that duplicate or are similar to Reference by Mail, detailed here, in order to formalize services to a vast, though often publicly forgotten, section of the public served by the public library. Formalization of services to people in jail and prison can be held with a denormalization of carceral systems - these services are, after all, an aftereffect of State practices of racial capitalism and dehumanization where lack of access to useful information is a form of state-sanctioned oppression. 
Information Provision and the Carceral State 38

\section{Notes}

1. This number does not include information on forced detention of immigrant populations, which is notoriously underreported.

2. The focus on American systems of policing in this article is intentional. It is undertaken with an awareness that American systems of policing and incarceration are based in international flows historically constructed through the slave trade and colonial extraction, that they have continuous international effects, that the American system of policing has been exported, and that the prison-industrial complex has implications that far exceed the country's borders (Chavez-Garcia, 2012; Daulatzai, 2012; Dunbar-Ortiz, 2012; Marquez \& Rana, 2017; Wagner, 2009).

3. The most recent American Library Association (ALA) Diversity Counts survey in 2012 found that $85 \%$ of librarians in the United States are white, and overwhelmingly white women. The Sentencing Project notes that the lifetime likelihood of imprisonment for U.S. residents born in 2001 is 1 in 9 men, 1 in 17 white men, 1 in 3 Black Men, 1 in 6 Latino men (The Sentencing Project, 2017).

4. The authors of this paper are cautious of, but not immune to, reproducing the "White lady bountiful" archetype that Schlesselman-Tarango (2018) carefully outlines. The authors recognize that we cannot remove ourselves from embedded systems of race, but that being aware of the tension and moving through the friction is where a more egalitarian information studies practice will emerge.

5. Ferguson (2014) notes that there has been a longstanding forensic interest in handwriting, typed copy, and fingerprinting as forms of evidence in criminal cases. Thornton also discusses this theme in Handwriting in America (1996). Contemporary forensic interests in handwriting 
are linked to the potential development of predictive policing models, and seek to establish an identifiable link between types of criminality and forms of script (Gawda, 2008). 


\section{References}

Ahmed, S. (2007). A phenomenology of whiteness. Feminist Theory, 8(2), 149-168. https://doi.org/10.1177/1464700107078139

Alabi, J. (2015). Racial microaggressions in academic libraries: Results of a survey of minority and non-minority librarians. The Journal of Academic Librarians, 41(1), 47-53. https://doi.org/10.1016/j.acalib.2014.10.008

Alexander, M. (2010). The new Jim Crow: Mass incarceration in the age of colorblindness. New York, NY: The New Press.

American Library Association. (2012). Diversity Counts survey. Retrieved from http://www.ala.org/aboutala/sites/ala.org.aboutala/files/content/diversity/diversitycounts/ diversitycountstables2012.pdf

American Library Association. (2018). Librarian ethnicity. Retrieved from http://www.ala.org/tools/librarian-ethnicity

American Library Association. (2019a). Prisoners' Right to Read: An Interpretation of the Library Bill of Rights. Retrieved from http://www.ala.org/advocacy/intfreedom/librarybill/interpretations/prisonersrightoread

American Library Association. (2019b). Revised Library Bill of Rights interpretations adopted at Seattle Midwinter meeting. Retrieved from http://www.ala.org/news/membernews/2019/02/revised-library-bill-rights-interpretations-adopted

Angel, C. M. (2016). Collaboration among faculty members and community partners: Increasing the quality of online Library and Information Science graduate programs through academic service-Learning. Journal of Library and Information Services in Distance Learning, 10(1/2), 4-14. 
Arford, T. (2016). Prisons as sites of power/resistance. In D. Courpasson \& S. Vallas (Eds.) The SAGE Handbook of Resistance (pp. 224 - 243). London: Sage Publications.

ASCGLA. (2017). The prison library as an agent of rehabilitative change. Retrieved from http://www.ala.org/asgcla/online-learning/the-prison-library

ASCLA ad hoc subcommittee. (1992). Library standards for adult correctional institutions. Chicago, IL: American Library Association.

Barnes, R. (1990). Race consciousness: The thematic content of racial distinctiveness in Critical Race scholarship. Harvard Law Review, 103, 1864-1871.

Barry, M., Lowe, L.A., \& Twill, S. E. (2017). Academic librarians' attitudes about civicmindedness and service learning. Library Quarterly, 87(1), 1-16. https://doi.org/10.1086/689311

Bauer, S. (2018). American prison: A reporter's undercover journey into the business of punishment. New York, NY: Penguin Press.

Bernstein, N. (2014). Burning down the house: The end of juvenile prison. New York, NY: The New Press.

Bouchard, J. \& Winnicki, A. (2000). "You found what in a book?" Contraband control in the prison library. Library \& Archival Security, 16(1), 47-61.

Bustamante, P., Jahnani, G. \& Stoudt, B. G. (2018). Theorizing cumulative dehumanization: An embodied praxis of 'becoming' and resisting State-sanctioned violence. Social and Personality Psychology Compass, 13(2). https://doi.org/10.1111/spc3.12429

Cacho, L. M. (2012). Social death: Racialized rightlessness and the criminalization of the unprotected. New York, NY: New York University Press.

Chatman, E. A. (1996). The impoverished life-world of outsiders. Journal of the American 
Society for Information Science, 47(3), 193-206.

Chatman, E. A. (1999). A theory of life in the round. Journal for the Association of Information Science \& Technology, 50(3), 207-217.

Chavez-Garcia, M. (2012). States of delinquency: Race and science in the making of California's juvenile justice system. Berkeley, CA: University of California Press.

Clark, S. \& MacCreigh, E. (2006). Library services to the incarcerated: Applying the public library model in correctional facilities. Santa Barbara, CA: Libraries Unlimited.

College Self-Study. (2017). The University: Graduate School of Library and Information Studies self-study, 2010-2017. Master's of Library and Information Studies. Prepared by the faculty of GSLIS and submitted to ALA Committee on Accreditation.

Colón-Aguirre, M. (2017). Service learning for improvement of customer service education in LIS. Education for Information, 33, 171-185.

Cooke, N. A., Sweeney, M. E., \& Noble, S. U. (2016). Social justice as topic and tool: An attempt to transform an LIS curriculum and culture. The Library Quarterly, 86(1), 107124. https://doi.org/10.1086/684147

Couvillon, E. \& Justice, A. (2016). Letters from the big house: Providing consumer health reference for Texas prisons. Journal of Hospital Librarianship, 16(4), 281-286.

Coyle, W. (1987). Libraries in prisons: A Blending of institutions. New Directions in Information Management (15). Westport, CN: Greenwood Press.

Critical Resistance. (2019). What is the PIC? What is abolition? Retrieved from http://criticalresistance.org/about/not-so-common-language/

DataUSA. (n.d.). Library science. Retrieved from https://datausa.io/profile/cip/25/\#demographics Daulatzai, S. (2012). Black star, crescent moon: The Muslim International and Black freedom 
beyond America. Minneapolis, MN: University of Minnesota Press.

Davis, A. (2003). Are prisons obsolete? New York, NY: Seven Stories Press.

Drabinski, E. \& Rabina, D. (2015). Reference services to incarcerated people, part I: Themes emerging from answering reference questions from prisons and jails." Reference \& User Services Quarterly, 55(1), 42-48.

Dunbar-Ortiz, R. (2016). An indigenous peoples' history of the United States. Boston, MA: Beacon Press.

Elmborg, J. (2016). Forword. In N. Pagowsky \& K. McElroy (Eds.) Critical Library Pedagogy Handbook (pp. vii-xii). Chicago, IL: Association of College and Research Libraries, a Division of the American Library Association.

Ferguson, R. (2014). The literary hand: Handwriting, fingerprinting, typewriting. Critical Quarterly, 56(1), 40-55.

Fine, M. \& Ruglis, J. (2009). Circuits and consequences of dispossession: The racialized realignment of the public sphere for U.S. youth. Transforming Anthropology, 17(1), 2033.

Gawda, B. (2008). A graphical analysis of handwriting of prisoners diagnosed with antisocial personality. Perceptual and Motor Skills,107(3), 862-872.

Gilmore, R. W. (2007). Golden gulag: Prisons, surplus, crisis, and opposition in globalizing California. Berkeley, CA: University of California Press.

Giulietti, C., Tonin, M. \& Vlassopoulos, M. (2017). Racial discrimination in local public services: A field experiment in the United States. IZA Discussion Paper 9290 and CESifo Working Paper 5537. Retrieved from http://ftp.iza.org/dp9290.pdf.

Gohr, M. (2017). Ethnic and racial diversity in libraries: How white allies can support 
arguments for decolonization. Journal of Radical Librarianship, 3, $42-58$.

Higgins, N. (2017). Get inside: Responsible jail and prison library service. Quick Reads for Busy Librarians. Chicago, IL: Public Library Association.

Honma, T. (2005). Trippin' over the color line: The invisibility of race in Library and Information Studies. Interactions: UCLA journal of education and information studies, 1(2), Article 2.

Jackson, S. (2012). So close: Writing that touches. New Writing: The International Journal for the Practice and Theory of Creative Writing 9, no. 3: 408-418.

Jacobson, E. (2018). Reference by Mail to incarcerated people. In K Adler, I. Beilin, \& E. Tewell (Eds.) Reference librarianship \& justice: History, praxis \& practice (pp. 151-159). Sacramento, CA: Library Juice Press.

Kumasi, K. D. \& Franklin Hill, F. (2011). Are we there yet? Results of a gap analysis to Measure LIS students' prior knowledge and actual learning of cultural competence concepts. Journal of Education for Library and Information Science, 52(4), 251-264.

Kutner, M. (2015). With no Google, the incarcerated wait for the mail. Newsweek. Retrieved from https://www.newsweek.com/people-behind-bars-google-answers-arrive-mail$\underline{301836}$

Lehmann, V. (2000). Prison librarians needed: A challenging career for those with the right professional and human skills. IFLA Journal, 26(2), 123-128. Retrieved from https://archive.ifla.org/IV/ifla65/papers/046-132e.htm

Lehmann, V. \& Locke, J. (2005). Guidelines for library services to prisoners. 3rd ed. International Federation of Library Associations and Institutions (IFLA), IFLA Professional Reports, No. 92. 
Lesko, N. (1996). Denaturalizing adolescence: The politics of contemporary representations. Youth \& Society, 28(2),139-161.

Márquez, J. D. \& Rana, J. (2017). Black radical possibility and the Decolonial International. South Atlantic Quarterly, 116(3), 505-528. https://doi.org/10.1215/00382876-3961461

Meiners, E. R. (2007). Right to be hostile: Schools, prisons, and the making of public enemies. New York, NY: Routledge.

Melamed, J. (2015). Racial capitalism. Critical Ethnic Studies, 1(1), 76-85.

National Association for the Advancement of Colored People (NAACP). (2019). Criminal justice fact sheet. Retrieved from https://www.naacp.org/criminal-justice-fact-sheet/

Nellis, A. (2016). The color of justice: Racial and ethnic disparity in state prisons." Retrieved from https://www.sentencingproject.org/publications/color-of-justice-racial-and-ethnicdisparity-in-state-prisons/

Overall, P. M. (2010). The effect of service learning on LIS students' understanding of diversity issues related to equity of access. Journal of Education for Library and Information Science, 51(4), 251-66.

Parsons, M. D. \& Plakhotnic, M. (2006). Invisible to the majority: The search for Critical Race Theory in the higher education and policy literature. Race, Gender \& Class, 13(3/4), 162175.

Patterson, O. (1982). Slavery and social death: A comparative study. Cambridge, MA: Harvard University Press.

Pawley, C. (2006). Unequal legacies: Race and multiculturalism in the LIS curriculum. The Library Quarterly: Information, Community, Policy, 76(2), 149-168.

Peterson, L. (1996). Alternative perspectives in Library and Information Science: Issues of race. 
Information Provision and the Carceral State 46

Journal of Education for Library and Information Science, 37(2), 163-174.

Prial, F. J. (1978). Library offers prisoners a key to needs." New York Times. Page B3. Retrieved from https://www.nytimes.com/1978/02/06/archives/library-offers-prisoners-a-key-toneeds-books-films-and-advice-are.html

Rabina, D. \& Drabinski, E. (2015). Reference services to incarcerated people, part II: Sources and learning outcomes. Reference \& User Services Quarterly, 55(2), 123-131.

Ritchie, A. J. \& Richie, B. E. (2017). The crisis of criminalization: A call for a comprehensive philanthropic response. New Feminist Solutions Series. New York, NY: Bernard Center for Research on Women. Retrieved from http://bcrw.barnard.edu/wpcontent/nfs/reports/NFS9-Challenging-Criminalization-Funding-Perspectives.pdf

Roberts, S. T. \& Noble, S. U. (2016). Empowered to name, inspired to act: Social responsibility and diversity as calls to action in the LIS context. Library Trends, 64(3), 512-532.

Roy, L. (2014). The place of service learning in reference education. Reference Librarian, 55(2), $168-171$.

Rubin, R. J. \& Suvak, D. (Eds). (1995). Libraries inside: A Practical guide for prison librarians. Jefferson, NC: McFarland \& Co.

Sakala, L. (2014). Breaking down mass incarceration in the 2010 census: State-by-state incarceration rates by race/ethnicity.” Retrieved from https://www.prisonpolicy.org/reports/rates.html

Schlesselman-Tarango, G. (2016). The legacy of Lady Bountiful: White women in the library. Library Trends, 64(4), 667-686. DOI: 10.1353/lib.2016.0015

Shirley, G. L. (2003). Correctional libraries, library standards, and diversity. Journal of Correctional Education, 54(2), 70-74. 
Spade, D. (2011). Normal life: Administrative violence, critical trans politics and the limits of law. Cambridge, MA: South End Press.

Stanley, E. \& Smith, N. (Eds.). (2011). Captive genders: Trans embodiment and the prison industrial omplex. Oakland, CA: AK Press.

Stearns, R. M. (2004). The prison library. Behavioral \& Social Sciences Librarian, 23(1), 4980.

Story, B. (Dir). (2016). The prison in twelve landscapes [Motion Picture]. Oh Ratface Films. Streaming.

Sullivan, L. E. (2000). The least of our brethren: Library service to prisoners. American Libraries, 31(5), 56-58.

Sullivan, L. E. (2008). Prison is dull today: Prison libraries and the irony of pious reading. PMLA, 123(3), 703-706.

Sweeney, M. (2008). Books as bombs: Incendiary reading practices in women's prisons. PMLA, 123(3), 666-673.

The Sentencing Project. (2017). Criminal justice facts. Retrieved from https://www.sentencingproject.org/criminal-justice-facts/

Thornton, T. P. (1998). Handwriting in America: A cultural history. New Haven, CT: Yale University Press.

Vargas, L. C. \& Erba, J. (2017). Cultural competence development, critical service learning, and Latino/a youth empowerment: A qualitative case study. Journal Of Latinos And Education, 16(3), 203-216. https://doi.org/10.1080/15348431.2016.1229614

Velez, L. \& Villa-Nicholas, M. (2017). Mapping race and racism in U.S. library history literature, 1997-2015." Library Trends, 65(4), 540-554. 
Vogel, B. (1995). Down for the count: A prison library handbook. Metuchen, NJ: Scarecrow Press.

Vogel, B. (2009). The prison library primer: A program for the twenty-first century. Lanham, MD: Scarecrow Press.

Wagner, B. (2009). Disturbing the peace: Black culture and the police power after slavery. Cambridge, MA: Harvard University Press.

Wang, J. (2018) Carceral capitalism. Semiotext(e) Intervention Series, 21. South Pasadena, CA: Semiotext(e).

Wiegand, W. A. (2000). American Library History Literature, 1947-1997: Theoretical Perspectives? Libraries \& Culture, 35(1), 4-34. 
Information Provision and the Carceral State 49

\section{Appendix A- Abbreviated List of Rules}

1. Patrons can receive responses to two letters per month. Each response will contain no more than 20 pages of information.

2. Respondents will not contact in individual on behalf of a patron, nor will they provide individually identifying information for people who are not public figures.

3. This service cannot offer legal advice. Any legal information contained in a response is the responsibility of the person who created the information, and may be inaccurate.

4. This service does not provide adult materials.

5. This service will not respond to inquiries that request information on weapons or request information used to promote violence.

6. This service does not provide real world maps or directions. Fantasy maps (Such as those for RPGs) are available through this service. 